\title{
Human Erythrocyte Carbonic Anhydrase B and G in Chronic Obstructive Lung Disease
}

\author{
Takahito Kondo, Naoyukr Taniguchi,* Yoshikazu \\ Kawakami, Hajime Ide, Kazuo SaIto* and Makoto Murao \\ The First Department of Internal Medicine and Department \\ of Hygiene and Preventive Medicine,* Hokkaido University \\ School of Medicine, Sapporo
}

Kondo, T., Tanigucht, N., Kawakami, Y., Ide, H., Saito, K. and Murao, M. Human Erythrocyte Carbonic Anhydrase $B$ and $C$ in Chronic Obstructive Lung Disease. Tohoku J. exp. Med., 1975, 117 (4), 351-356 - The levels of carbonic anhydrase $\mathrm{B}$ and $\mathrm{C}$ isozymes in human red cells were determined using a quantitative immunological technique in patients with chronic obstructive lung disease. A significant increase in the level of carbonic anhydrase $B$ was observed in these patients, while the level of carbonic anhydrase $\mathrm{C}$ did not change substantially. Positive correlations were found between the level of carbonic anhydrase $B$ and arterial $\mathrm{CO}_{2}$ tension and plasma $\mathrm{HCO}_{3}^{-}$concentration. A negative correlation was observed between the levels of carbonic anhydrase $\mathrm{B}$ and blood $\mathrm{pH}$. These findings suggest that the synthesis or degradation of carbonic anhydrase $\mathrm{B}$ isozyme is affected by arterial $\mathrm{CO}_{2}$ tension or plasma $\mathrm{HCO}_{3}^{-}$concentration. The clinical significance was also discussed in relation to these isozyme levels in red cell. — carbonic anhydrase $\mathrm{B}$ and $\mathrm{C}$ isozymes; chronic obstructive lung disease; hypercapnia

Human carbonic anhydrase ( $\mathrm{E} C \mathrm{C}$ 4.2.1.1) has two major types of isozymes designated as $\mathrm{B}$ type (CA-B) and $\mathrm{C}$ type (CA-C). Immunologically these two types of isozymes do not show any cross reaction with each other (Funakoshi and Deutsch 1970) and were genetically controlled by different loci of the gene (Tashian 1969; Deutsch et al. 1972b). As a catalyzer for the reversible hydration of $\mathrm{CO}_{2}$, the enzyme plays an important role in the transport of $\mathrm{CO}_{2}$ and acid base equilibrium (Dubois 1969; Lindskog et al. 1971; Maren 1971). The levels of CA-B and $\mathrm{CA}-\mathrm{C}$ are changed under some pathological or physiological conditions as reported previously (Funakoshi and Deutsch 1971; Matsuo 1972; Mochizuki 1972; Mondrup and Anker 1974; Sell and Petering 1974; Taniguchi et al. 1975; Kondo et al. 1975). Chronic obstructive lung disease (C.O.L.D.) is defined as a disease with chronic obstruction to airflow in the lungs. The common causes are emphysema, chronic bronchitis, and certain forms of asthma (Thurbeck et al. 1970). Patients with C.O.L.D. have a reduced capacity to eliminate $\mathrm{CO}_{2}$ from the alveoli and hence tend to develop chronic hypercapnia. It is of interest to know the changes in levels of carbonic anhydrase isozymes under these conditions. This

Received for publication, July 5, 1975. 
paper describes the levels of erythrocyte CA-B and CA-C using immunological technique in the patients with C.O.L.D. in order to examine whether or not the changes in arterial $\mathrm{CO}_{2}$ tension $\left(\mathrm{PaCO}_{2}\right)$ or plasma $\mathrm{HCO}_{3}^{-}$concentration affect the levels of erythrocyte $\mathrm{CA}-\mathrm{B}$ or $\mathrm{CA}-\mathrm{C}$.

\section{Materials and Methods}

Subjects. Thirty six blood samples obtained from eighteen patients diagnosed as C.O.L.D. in various elinical stages, admitted to the Hokkaido University Hospital, were used for this study. C.O.L.D. patients accompanied with kidney or blood disorders were excluded. Sixteen patients were male and two were female, with an average age of 60 years. They had $\mathrm{PaCO}_{2}$ levels of $47.0 \pm 1.58 \mathrm{mmHg}$ (mean \pm S.e.) ranging from $35 \mathrm{mmHg}$ to $76.5 \mathrm{mmHg}, \mathrm{pH}$ values of $7.364 \pm 0.01$ (mean \pm S.E.) ranging from 7.290 to 7.412 , and $\mathrm{HCO}_{3}^{-}$concentrations of $26.17 \pm 0.80 \mathrm{mEq} / \mathrm{liter}$ (mean \pm s.e.) ranging from $20.0 \mathrm{mEq} / \mathrm{liter}$ to $41.5 \mathrm{mEq} /$ liter. The levels of CA-B and CA-C in normal adults were reported elsewhere (Taniguchi et al. 1974; Kondo et al. 1975). These values were employed in the present work as control. Determination of $\mathrm{Paco}_{2}$ and blood $\mathrm{pH}$ was measured by a blood gas microanalyzer (Radiometer, BMS-MK, 2, Kopenhagen). Plasma $\mathrm{HCO}_{3}^{-}$concentration was determined using an acid-base alignment nomogram according to Siggaard-Andersen (Siggaard-Andersen 1960).

Purification of carbonic anhydrase $B$ and $C$ types. Human red cell carbonic anhydrase isozymes were purified with a slightly modified method (Taniguchi et al. 1974) used for horse enzymes originally by Deutsch et al. (1972a).

Specific antisera. Specific antisera against carbonic anhydrase isozymes were prepared by subcutaneous injection of purified enzymes with Freund's complete adjuvant in draft horses as described previously (Taniguchi et al. 1975). Antisera thus obtained showed a single precipitin line to each isozyme.

Preparation of hemolysates. One $\mathrm{ml}$ of arterial blood collected in heparinized tubes was used as specimens. Whole blood was centrifuged to remove the plasma, and packed blood cells were washed twice with ten volumes of isotonic saline by subsequent centrifugation. By repeated freezing at $-80^{\circ} \mathrm{C}$ and thawing, packed blood cells were hemolyzed. Stroma was removed from the hemolysates by centrifugation at $10,000 \times \mathrm{g}$ fro $30 \mathrm{~min}$. Hemoglobin contents of hemolysates were measured by the cyanmethohemoglobin method (Van Kampen and Zijlstra 1961). The hemoglobin content of hemolysates was adjusted to approximately $5 \mathrm{~g} / 100 \mathrm{ml}$ with isotonic saline before the immunological assay.

Immunological measurement. $\mathrm{CA}-\mathrm{B}$ and $\mathrm{CA}-\mathrm{C}$ isozymes were assayed according to the method described previously (Dubois 1969) Antigen concentration was determined spectrophotometrically at $280 \mathrm{~nm}$ using $\mathrm{E}_{1 \mathrm{~cm}}^{1 \%}$ at $280 \mathrm{~nm}=16.3$ for $\mathrm{CA} \cdot \mathrm{B}$ and 18.7 for CA-C, respectively (Nyman and Lindskog 1974). The levels of CA-B and CA-C were expressed as $\mathrm{mg}$ enzyme per $\mathrm{g}$ hemoglobin.

\section{Results}

Carbonic anhydrase $B$ and $C$ levels in patients with chronic obstructive lung disease and normal subjects

Table 1 shows the mean and standard errors of the levels of CA-B and CA-C in the red cells of patients with C.O.L.D. and these in normal subjects. The levels of CA-B in patients with C.O.L.D. were significantly higher than those in 
TABLE 1. Levels of human carbonic anhydrase

\begin{tabular}{lccc}
\hline Subjects & $\begin{array}{c}\text { Number of } \\
\text { cases }\end{array}$ & $\begin{array}{c}\text { CA-B } \\
\text { (mg/g-Hb s.E.) }\end{array}$ \\
\hline $\begin{array}{c}\text { Normal male (Taniguchi et al. 1974; } \\
\text { Kondo et al. 1975) }\end{array}$ & 94 & $13.08 \pm 0.42$ & $1.70 \pm 0.03$ \\
$\begin{array}{l}\text { Normal female (Taniguchi et al. 1974; } \\
\text { Kondo et al. 1975) }\end{array}$ & 40 & $14.21 \pm 0.86$ & $1.74 \pm 0.04$ \\
C.O.L.D. & 36 & $17.90 \pm 0.58$ & $1.58 \pm 0.09$ \\
\hline Values a & & &
\end{tabular}

Values are expressed as mean \pm s.E. C.O.L.D., chronic obstructive lung disease.

normal subjects $(p<0.001)$, while no substantial differences were observed in the levels of CA-C.

Relations between the levels of carbonic anhydrases and $\mathrm{Paco}_{2}$, plasma $\mathrm{HCO}_{3}$ concentration and blood $\mathrm{pH}$

The levels of CA-B in red cells were positively correlated to $\mathrm{PacO}_{2}$ and plasma $\mathrm{HCO}_{3}^{-}$concentration. As shown in Figs 1. and 2. the correlation coefficient showed $\mathrm{r}$ values of $0.703(p<0.01)$ and $0.604(p<0.01)$, respectively. No correlations were seen between the levels of $\mathrm{CA}-\mathrm{C}$ and the $\mathrm{Paco}_{2}$ or plasma $\mathrm{HCO}_{3}^{-}$concentration. As shown in Fig. 3, CA-B level increases as blood $\mathrm{pH}$ decreases $(\mathrm{r}=0.351, p<0.05)$. $\mathrm{PacO}_{2}$ levels of $45 \mathrm{mmHg}$ and plasma $\mathrm{HCO}_{3}^{-}$levels of $25 \mathrm{mEq} /$ liter are considered to be the upper limit of normal ranges. According to Fig. 1, patients with $\mathrm{Paco}_{2}$ of $45 \mathrm{mmHg}$ or higher have higher levels $\mathrm{CA}-\mathrm{B}$ than those of normal subjects. As shown in Fig. 2, the levels of $\mathrm{CA}-\mathrm{B}$ were elevated when $\mathrm{HCO}_{3}^{-}$ concentration increased over $25 \mathrm{mEq} /$ liter.

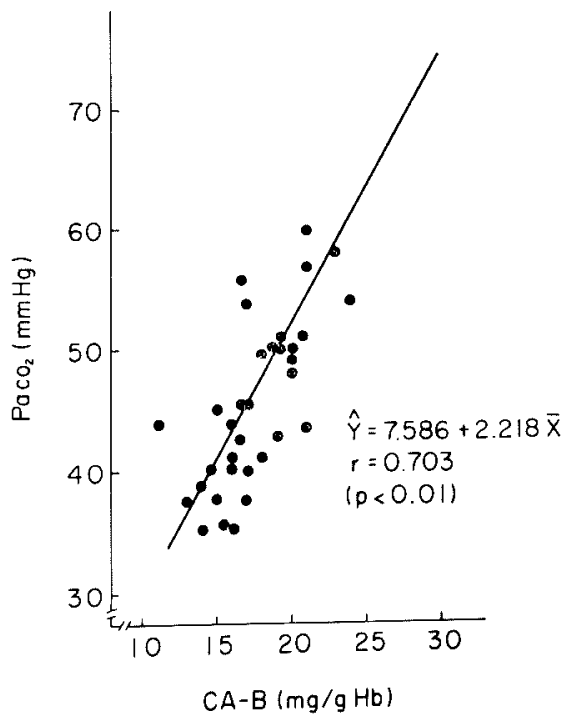

Fig. 1. Correlation between $\mathrm{P}_{\mathrm{acO} 2}$ and CA-B in patients with C.O.L.D. 


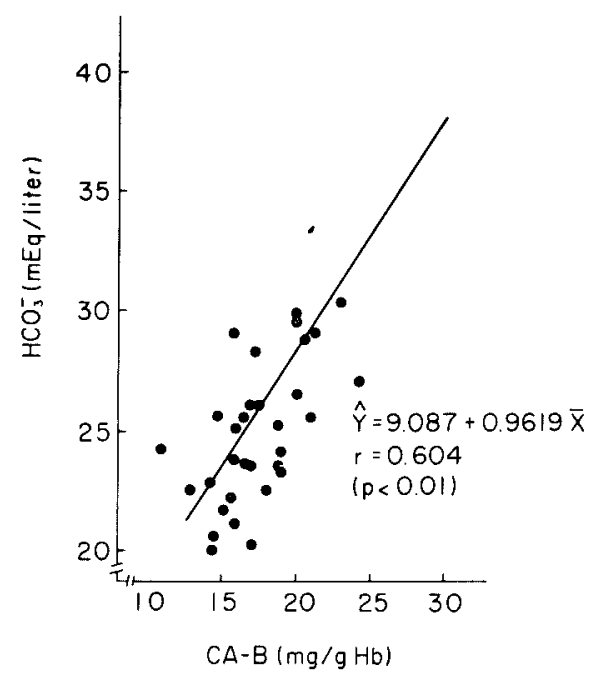

Fig. 2. Correlation between $\mathrm{HCO}_{3}^{-}$and CA-B in patients with C.O.L.D.

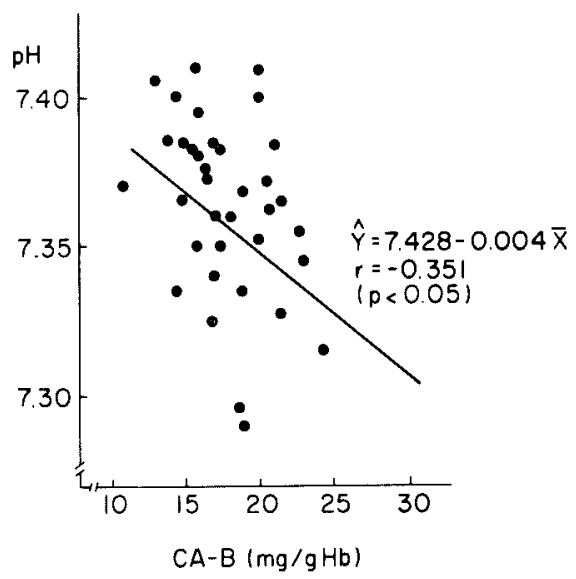

Fig. 3. Correlation between blood $\mathrm{pH}$ and $\mathrm{CA}-\mathrm{B}$ in patients with C.O.L.D.

\section{Discussion}

Patients with C.O.L.D. were shown to have relatively higher levels of carbonic anhydrase $B$ in red cells than those of normal healthy adults. The results obtained also suggested that the changes in $\mathrm{PacO}_{2}$ of plasma, $\mathrm{HCO}_{3}^{-}$concentrations and blood $\mathrm{pH}$ are well correlated to the changes in $\mathrm{CA}-\mathrm{B}$ levels in red cells. Patients with normal ranges of $\mathrm{Paco}_{2}$ and plasma $\mathrm{HCO}_{3}^{-}$concentrations have a normal value of $\mathrm{CA}-\mathrm{B}$ in red cells. Patients with the values over normal ranges, however, showed increased levels of CA-B. It is of interest to acertain whether high levels of carbonic anhydrase have any significant influence on the $\mathrm{CO}_{2}$ exchange in the lung capillaries of C.O.L.D. Roughton (1964) emphasized the importance of carbonic 
anhydrase in the physiolosical transport of $\mathrm{CO}_{2}$ and described the possible influence of the activity of carbonic anhydrase on $\mathrm{CO}_{2}$ exchange in the lung tissues. Funakoshi and Deutsch (1971) reported that patients with emphysema had high levels of erythrocyte CA-B, and Lie-Injo et al. (1970) reported that patients with chronic lung disease had a high activity of this enzyme. The present results are in good agreement with these previous studies.

Hypoventilation and ventilation/perfusion abnormalities in C.O.L.D. results in the $\mathrm{CO}_{2}$ retention and in severe cases give rise to hypercapnia or respiratory acidosis. In C.O.L.D., an adaptive increase in CA-B levels in red cells may well occur in order to meet with an adequate $\mathrm{CO}_{2}$ exchange in lungs and tissues. The regulatory mechanism of the levels of carbonic anhydrase in red cells, however, is not well known. As to whether $\mathrm{CO}_{2}$ tension in the alveoli affects primarily the carbonic anhydrase levels in red cells is also not well understood.

Our previous report indicated that the esterase activities of CA-B increased proportionally as the increase of CA-B protein in patients with C.O.L.D., and so "true" specific activity of CA-B enzyme was within normal ranges (Kondo et al. 1975). These facts also suggest that an adaptive increase in CA-B protein may occur and CA-B enzyme protein was revealed to be functionally active in these patients. These increases in CA-B levels might depend on the increase in CA-B protein synthesis or the decrease in the degradation of this enzyme protein. We are at present continuing work along this line to clarify this point.

\section{References}

1) Deutsch, H.F., Funakoshi, S., Fujita, T.. Taniguchi, N. \& Hirai, H. (1972a) Isolation in crystalline form and properties of six horse erythrocyte carbonic anhydrases. J. biol. Chem., 277, 4499-4502.

2) Deutsch, H.F., Taniguchi, N., Funakoshi, S. \& Hirai, H. (1972b) Distribution of erythrocyte carbonic anhydrase B-type alles in Japanese farm horses. Biochem. Genet., 6, 255-262.

3) Dubois, A.B. (1969) Significance of carbonic anhydrase in lung tissue. In: $\mathrm{CO}_{2}$; Chemical, Biochemical and Physiological Aspects, edited by R.E. Forster, J.T. Edsall, A.B. Otis \& F.J.W. Roughton, NASA sp-188, Washington, pp. 257-259.

4) Funakoshi, S. \& Deutsch, J.F. (1970) Human carbonic anhydrase. J. biol. Chem., $245,2852-2856$.

5) Funakoshi, S. \& Deutsch, H.F. (1971) Human carbonic anhydrases V. levels in erythrocytes in various states. J. Lab. clin. Med., 77, 39-45

6) Kondo, T., Taniguchi, N., Murao, M. \& Takakuwa, E. (1975) Estimations of active and inactive carbonic anhydrase isozyme $\mathrm{B}$ in human red cells. Clin. chim. Acta, $60,347-353$.

7) Lie-Injo, L.E. Lopez, C.G. \& Hart, P.L.D. (1970) Erythrocyte carbonic anhydrase activity in health and disease. Clin. chim. Acta, 29, 541-550.

8) Lindskog, S., Henderson, L.E., Kannan, K.K., Liljas, A., Nyman, P.O. \& Strandberg, B. (1971) Carbonic anhydrase. In: The Enzymes, vol. V, P.D. Boyer, Academic Press, New York, pp. 587-665.

9) Matsuo, W. (1972) Carbonic anhydrase quantity in the blood of newborns. Tohoku J. exp. Med., 107, 47-56.

10) Maren, T.H. (1971) Unifying ideas concerning the physiolosy of carbonic anhydrase. In: Oxygen Affinity of Hemoglobin and Red Cell Acid Base Status, edited by M. Rorth 
\& P. Astrup, Academic Press, New York, pp. 418-433.

11) Mochizuki, K. (1972) Carbonic anhydrase quantity of red cells in norbus basedowii. Tohoku J. exp. Med., 108, 401-409.

12) Mondrup, M. \& Anker, M. (1974) Carbonic anhydrase isozyme B in the erythrocyte of uremic subjects. Clin. chim, Acta, 51, 141-146.

13) Nyman, P.O. \& Lindskog, S. (1974) Amino acid composition of various forms of bovine and human erythrocyte carbonic anhydrase. Biochim. biophys. Acta, 85, 141-151.

14) Roughton, F.J.W. (1964) Transport of oxygen and carbon dioxide. In: Handbook of Physiology, edited by W.O. Fenn \& H. Rann, Sec. 3: Respiration, Vol. 1, American Physiological Society, Washington, D.C., pp. 767-825.

15) Sell, J.E. \& Petering, H.G. (1974) Carbonic anhydrases from human neonatal erythrocytes. J. Lab. clin. Med, 84, 369-377.

16) Siggaard-Andersen, O. (1960) Blood gas concentrations. Scand. J. clin. Lab. Invest., 12, 172-176.

17) Taniguchi, N., Kondo, T., Saito, K. \& Takakuwa, E. (1974) Immunological determinations of human erythrocyte carbonic anhydrase isozymes. Igaku no Ayumi (Jap.), 91, 133-136.

18) Taniguchi, N., Sato, T., Kondo, T., Tamachi, H., Saito, K. \& Takakuwa, E. (1975) Carbonic anhydrase isozymes, Hemoglobin-F and gluthatione levels. In lead exposed workers. Clin. chim. Acta, 59, 29-34.

19) Tashian, R.E. (1969) The esterase and carbonic anhydrases of human erythrocyte. In: Biological Methods in Red cell Genetics, edited by J.J. Yunis, Academic Press, New York, pp. 307-334.

20) Thurbeck, W.M., Henderson, T.A., Fraster, R.G. \& Bates, P.V. (1970) Chronic obstructive lung disease. Medicine, 49, 81-145.

21) Van Kampen, E.J. \& Zijlstra, W.G. (1961) Standardization of hemoglobinometry. Clin. chim. Acta, 6, 538-544. 